\title{
A Functional Interpretation of Company Brochures - from Context to Text
}

Genre analysis, or the study of functional variations of language, is an area of linguistics which has received considerable attention since its introduction in the 1960s. The description of genres has progressed from an identification of statistically significant linguistic properties (e.g. Halliday et al. 1964) through a concern with the rhetorical function of linguistic features (Selinker, Lackstrom \& Trimble 1973), the organisation of texts (Widdowson 1973, Hoey 1979), and finally to a primary concern with the communicative purpose of genres (Martin 1985a, 1985b, Swales 1990, Bhatia 1993, Eggins 1994, Eggins $\&$ Martin 1997). Thus when trying to define and describe genres today, the identification of the purpose of a particular language variety is regarded as a useful place to begin.

This thesis (Askehave 1998) presents an exemplary analysis of the purpose ${ }^{1}$ of two instances of one particular genre - namely the company brochure.

It is often maintained that the main purpose of company brochures is to describe various concrete aspects of a particular company (e.g. its production facilities, markets, employees, etc.). However, this thesis claims that these aspects merely account for the content of the brochures whereas the purpose of a company brochure is quite different.

This thesis suggests that the purpose of a company brochure is to present the company as a qualified partner. In other words that manufacturers use their company brochures to demonstrate that they possess the qualities needed to enter into long-lasting trading relationships with potential customers.

In order to look for support for this idea two dimensions of language use are considered; the cultural context in which company brochures are used and particular linguistic features of the company brochures.

1 The problem with the term the 'purpose' of a text is that texts are multifunctional. Thus the same text may serve a wide range of purposes (see also Swales 1990: 47). This means of course that company brochures may serve many different purposes. However, the aim of this thesis is to account for what the author believes is the main purpose of company brochures. 
The contextual analysis of the brochures (focusing on the industrial market in which company brochures are used) is based on a theory of sociology - the so-called Network Approach (Hammerkvist et al. 1982 and Johansson 1989).

The linguistic analysis of two company brochures - one from an Irish dairy ingredient manufacturer (Kerry Foods) and one from an English packaging manufacturer (Poly-Lina) draws heavily on a systemic functional approach to text analysis (Halliday 1994).

The thesis is divided into two main parts. Part I discusses the basic tenets and central concepts of Systemic Functional Linguistics and lays the foundation for the analyses made in Part II.

Part II contains the contextual and linguistic analyses of the company brochures from Poly-Lina (PL) and Kerry Foods (KF).

In the rest of this summary focus will be on Part II - i.e. the analyses and their results.

The analysis of the cultural context of company brochures tries to establish how interaction takes place in the industrial market where the KF and PL brochures are used. Research carried out within the Network Approach demonstrates that the establishment of long-lasting trading relationships is paramount in today's industrial market. It follows from this that one of the main marketing objectives is to promote the companies' capability of cooperating with potential customers. On the basis of the observations made by the Network researchers it is concluded that even though company brochures cannot establish partnerships in themselves, they can facilitate the establishment by presenting the company as a qualified partner. In the company brochures this facilitation can be achieved by focusing on a range of partnership qualities such as Innovation, Skills, Quality, Customer Care, Cooperation, Size/Extent, Continuity/Stability and Experience which are important qualities to possess if a company is to appear as a qualified partner.

After having found indication of contextual support for the hypothesis concerning the purpose of company brochures, the analysis goes on to look at linguistic features in the brochures to find manifestations of the suggested purpose in the texts. The partnership qualities arrived at by examining the cultural context form the basis of three linguistic analyses:

1. Analysis of lexemes

2. Analysis of transitivity patterns ${ }^{2}$

2 'Transitivity' is a concept from Systemic Functional Linguistics which is used to refer to the grammatical resource for construing 'what is going on' - represented as a configuration of processes, participants and circumstances. 


\section{Analysis of Theme and New-Rheme patterns ${ }^{3}$}

The analysis of lexemes attempts to organise lexemes in the Kerry Foods and the Poly-Lina texts in terms of semantic fields of partnership qualities. The purpose of this analysis is to find out whether the choice of lexemes in the texts demonstrates a concern with partnership qualities i.e. whether the presentation of the companies is made with a view to promoting various partnership qualities. It turns out that lexemes encoding meanings of partnership qualities are extremely frequent throughout both company brochures.

The identification of partnership qualities in the texts in terms of lexemes encoding meanings of partnership qualities is then used as the basis for the study of transitivity and Theme/New-Rheme patterns in the next two linguistic analyses.

The analysis of transitivity structures demonstrates that in both company brochures material processes are to a very large extent concerned with processes essential for working in partnership. Thus very often lexemes positioned as processes signify partnership qualities of Cooperation (to work with you), Customer Care (to supply, to offer) and Innovation (to develop) and the companies (and in the KF text - its customers) are construed as Actors of these 'partnership' processes. The relational processes are used to relate the company (and in the KF text - the customers) to various partnership qualities. This means that description and identification of the companies (and their customers) are made in terms of partnership qualities. Causative processes are used to assign additional partnership qualities to the companies or their customers.

Finally, it turns out that most circumstances apart from specifying location, time, manner, etc. also encode meanings of partnership qualities. Circumstances of manner refer for example to how the companies work with their customers namely 'in partnership' and 'hand in hand'.

The last analysis - the analysis of Theme/New-Rheme patterns - focuses on the lexical items functioning as Themes and New-Rhemes. The Themes in the brochures usually refer to the companies (or in the KF text - its customers) thus emphasising that the clauses in the texts are mostly about the companies or potential customers. On the other hand the New-Rhemes in the texts tend to refer to lexemes encoding meanings of partnership qualities. In other words the organisation of the clause as a message, shows that the clauses are about the companies and their customers. But what is more important - the newsworthy

3 The concepts of 'Theme' and 'New-Rheme' are also from the systemic functional tradition. 'Theme' is the element which serves as 'the starting-point for the message; it is the ground from which the clause is taking off' (Halliday, 1994). New-Rheme indicates the newsworthiness of the clause - and according to Fries (1992 and 1994) reflects the purpose of the text. 
information given about the companies or their customers is usually concerned with partnership qualities.

On the basis of the observations made above concerning the cultural context in which company brochures are used and particular linguistic features such as lexemes, transitivity and Theme/New-Rheme patterns, the thesis concludes that the results of the analyses seem to support the suggested idea that the purpose of the Kerry Foods and the Poly Lina brochures is to present the companies as qualified partners. However, it is stressed that an analysis of two company brochures does not provide quantitative evidence for the suggested purpose of company brochures. In order to look for additional support more data has to be investigated.

\section{References}

Askehave, I. (1998). A Functional Interpretation of Company Brochures - from context to text. $\mathrm{PhD}$ thesis. The Aarhus School of Business.

Bhatia, V.K. (1993). Analysing Genre: language use in professional settings. Longman.

Eggins, S. (1994). An Introduction to Systemic Functional Linguistics. Pinter Publishers.

Eggins, S. \& Martin, J.R. (1997). Genres and Registers of Discourse. In van Dijk, T.A. (ed) Discourse as Structure and Process - Discourse Studies: a multidisciplinary introduction, vol. I. Sage Publications.

Fries, P.H. (1992). The Structuring of Information in Written English Text. In Language Sciences Vol. 14. 4. 461-488.

Fries, P.H. (1994). On Theme, Rheme and Discourse Goals. In Coulthard, M. (ed). Advances in Written Text Analysis. Routledge.

Halliday, M.A.K. McIntosh, A. \& Strevens, P. (1964). The Linguistic Sciences and Language Teaching. The English Language Book Society and Longman Group Ltd.

Halliday; M.A.K. (1994) (2nd ed.).An Introduction to Functional Grammar. Edward Arnold.

Hammarkvist, K.O., Håkansson, H. \& Mattsson, L.G. (1982). Marknadsföring för konkurrenskraft. Liber.

Hoey, M. (1979). On the Surface of Discourse. George Allen and Unwin.

Johanson, J. (1989). Business Relationships and Industrial Networks. In Reprint Series. 7. Uppsala University Press.

Martin, J.R. (1985a). Factual Writing: exploring and challenging social reality. Deakin University Press.

Martin, J.R. (1985b). Process and Text: two aspects of semiosis. In Benson J.D. \& Greaves. W.S. (eds). Systemic Perspectives on Discourse, Vol, I: selected theoretical papers from the 9th International Systemic Workshop. Ablex. 
Selinker, L., Lackstrom, J. \& Trimble, L. (1973). Technical rhetorical principles and grammatical choice. In TESOL Quarterly 7 (2).

Swales, J.M. (1990). Genre analysis - English in academic and research settings. Cambridge University Press.

Widdowson, H.G. (1973). An applied linguistics approach to discourse analysis. Unpublished PhD thesis. University of Edinburgh. 
